\title{
Assessment of different rates of NPK fertilizer on the growth and yield components of two exotic okra (Abelmoschus esculentus L.) western urban of Sierra Leone
}

\author{
Ngegba, P. M. ${ }^{1}$, Kanneh, S. M. ${ }^{1}$ \& Quee, D. D. ${ }^{2}$ \\ ${ }^{I}$ Kabala Horticultural Crops Research Centre and Sierra Leone Agricultural Research Institute \\ ${ }^{2}$ Njala Agricultural Research Centre and Sierra Leone Agricultural Research Institute \\ PMB 1313 Tower Hill, Freetown, Sierra Leone \\ Author for correspondence: patdousnges@yahoo.com
}

\begin{abstract}
Summary: The experiment was conducted in an Inland Valley Swamp during the dry spell of 2017 laid out in a randomized complete block design (RCBD) three replications at the Kabala Horticultural Crops Research Centre (KHCRC) cropping site, Ogoo Farm of the Sierra Leone Agricultural Research Institute (SLARI), Freetown, Sierra Leone. Raised beds measuring $5 \mathrm{~m}$ x $1 \mathrm{~m}\left(6 \mathrm{~m}^{2}\right)$ with a $1 \mathrm{~m}$ furrow between beds. Inter and intra row spacing of $75 \mathrm{~cm}$ by $50 \mathrm{~cm}$ with two rows per bed and two seeds per hills were directly sown. The treatments constituted NPK 15:15:15 at the rate of $0,90,120$ and $150 \mathrm{~kg} /$ ha designated as $\mathrm{T}_{1}, \mathrm{~T}_{2}, \mathrm{~T}_{3} \& \mathrm{~T}_{4}$ and Two hybrids of okra were used as experimental materials obtained from Indo-American Hybrid Seed Company, India; Okra-WASA-HyOKR-1 and Okra-WASA-HyOKR-2. Seeds were treated with Thiram Poison for longevity. Result indicates $\mathrm{T}_{2}(25.2 ; 35.1 \mathrm{~cm})$ and $\mathrm{T}_{4}(56.9 \mathrm{~cm})$ treatments recorded tallest plant heights followed by $\mathrm{T}_{2}(24.0,34.4 \& 50.1 \mathrm{~cm})$, while $\mathrm{T}_{1}(18.8,28.4 \&$ $33.3 \mathrm{~cm})$ had the shortest plant heights at $4,8 \& 10$ Week After Planting respectively. Similarly, $\mathrm{T}_{4} \& \mathrm{~T}_{2}(38.9,65.5 \& 44.8 \mathrm{~cm})$ exhibited the largest $\mathrm{SG}$ and $\mathrm{T}_{1}(21.7,33.0 \& 52.0 \mathrm{~cm})$ the least values at 4, $8 \& 10$ Week After Planting. While, the widest and narrowest LA at 4, 8 \& $10 \mathrm{Week}$ After Planting was observed in $\mathrm{T}_{3}\left(131.3,135.0 \& 158.5 \mathrm{~cm}^{2}\right)$ and $\mathrm{T} 1\left(120.8,121.8 \& 128.1 \mathrm{~cm}^{2}\right)$. With respect to yield and yield components, the longest $(22.0 \mathrm{~cm})$ and heaviest $(112.7 \mathrm{~g})$ fruit were recorded by $\mathrm{T}_{3}$ followed by $\mathrm{T} 2(19.1 \mathrm{~cm} \mathrm{\&} 101.3 \mathrm{~g})$ with $\mathrm{T}_{1}$ having the shortest $(11.7 \mathrm{~cm})$ and lightest $(52.3$ g). The width of pod in T3 $(31.2 \mathrm{~cm})$ was greater than the rest of treatments and as usual, $\mathrm{T}_{1}$ indicated the least value $(14.6 \mathrm{~cm})$ respectively. The average NP produced plant ${ }^{-1}$ was shown by $\mathrm{T}_{2} \& \mathrm{~T}_{3}(4.0)$ with the least of fruit produced by $\mathrm{T}_{1}(2.0)$. Also, $100 \mathrm{seed}$ weight, $\mathrm{T}_{3}(106.7 \mathrm{~g})$ weighted the highest followed by $\mathrm{T}_{2}(103.3 \mathrm{~g})$, while $\mathrm{T}_{1}(60.3 \mathrm{~g})$ accounted for the lowest seed weight. Conclusively, the two materials are adaptable to the climatic conditions of Sierra Leone (Western area). Hence further evaluation required across vegetable growing zones.
\end{abstract}

Ngegba, P. M., Kanneh, S. M., Quee, D. D. (2020): Assessment of different rates of NPK fertilizer on the growth and yield components of two exotic okra (Abelmoschus esculentus L.) western urban of Sierra Leone. International Journal of Horticultural Science 26: 5559. https://doi.org/ 10.31421/IJHS/26/2020/5439

Key words: assessment, fertilizer, okra, yield components

\section{Introduction}

Vegetables are essential food for the human health and for the prevention of human diseases. They consist of several essential food ingredients, which can be successfully apply for repair the diseased body (Adekiya et al., 2019).

Okra (Abelmoschus esculentus L.) (Moench) comes from the Mallow family. Okra domesticated in West and Central Africa in the first time, but is now widely grown throughout the tropical countries, mainly for local markets (Ijoyah \& Dzer, 2012). Okra is an herbaceous annual crop with thick branched, semi-woody stem that can reach an average height of $4 \mathrm{~m}$. It has large lobe, rough, bristly leaves and shiny yellow flowers with a purple center. Although principally the crop is grown for its immature fruits, okra has varieties and integral uses.

It is an essential food vegetable due to its economic and nutritive values and it contains vitamins $\mathrm{A}, \mathrm{B}$ and $\mathrm{C}$; calcium and iron (Politud, 2016). Okra is contains more calcium than tomato or eggplant. It is also a good source of dietary fiber, a fat-free and low calorie food that makes it an ideal candidate for weight loss diets. Essentially, the young pods are mostly rich in nutrients with $86.1 \%$ moisture content, $9.7 \%$ carbohydrates, $12.2 \%$ protein, $0.1 \%$ fibre, $0.2 \%$ fats and $0.9 \%$ ash (Ojo et al.,
2012). Seeds of okra have very high protein content. In addition to food uses, okra can also be exploited for cattle feeds. The fibrous stems are used to card paper and textiles and as substitute to jute. Similarly, it has also a number of medical applications (Politud, 2016).

There are several varieties of okra differing in fruiting time and shape, colour of leaves and stem length (Madisa et al., 2015). The mostly cultivated species are Abelmoschus caillei (A. Chev) and Abelmoschus esculentus (L.) Moench. A. caillei is an unconventional okra species which grows naturally in many parts of West Africa whereas A. esculentus is a conventional type which is a native of Asia (Madisa et al., 2015). They grow up to 1.2-1.5 $\mathrm{m}$ in height and take about 55-58 days to fruit. The immature fruits are ready for fresh harvest between three and seven days after flowering (Madisa et al., 2015). According to Konyeha \& Alatise (2013), the total world production of okra was estimated at 4.99 million metric tons, cultivated from an area of 0.78 million hectares with an average yield of $6.39 \mathrm{t} \mathrm{ha}^{-1}$. However, yield of 12 to $15 \mathrm{t} \mathrm{ha}^{-1}$ farm gate price have been reported with income generation percentage about 40 to $80 \%$ of okra (PCARRD, 2007). Although okra is not a new crop in Sierra 
Leone, it is of economic importance in the country because it is widely consumed in almost every household daily. One of the major aspects of crop production and management which limit crop production is improper fertilizer type and rate of application and to some extent erratic environmental factors. Although there has been some research on okra, however, there is inadequate data on the yield of okra in Sierra Leone. Information regarding appropriate rates of NPK on the growth and yield of okra is virtually empty. Therefore, any attempts to generate data for the development of data bank on the yield of okra needs not be over emphasized. The aim of this study was to assess the effect of different rates of NPK fertilizer on the growth and yield components of two exotic okra hybrids in Sierra Leone.

\section{Materials and methods}

The experiment was conducted in an Inland Valley Swamp during the dry spell of 2017 at the Kabala Horticultural Crops Research Centre (KHCRC) site Ogoo Farm of the Sierra Leone Agricultural Research Institute (SLARI), Freetown. The soils at the location are alluvial with well-drained structure. The location has a monomodal rainfall pattern, with the rainy season stretching from May to September and the dry from October to April. Raised beds measuring $5 \mathrm{~m} \times 1 \mathrm{~m}\left(6 \mathrm{~m}^{2}\right)$ with a $1 \mathrm{~m}$ furrow between beds and replications were constructed. Inter and intra row spacing of $75 \mathrm{~cm}$ by $50 \mathrm{~cm}$ with two rows per bed and two seeds per hills were directly sown. The experiment was laid out in a Randomized Complete Block Design (RCBD) with three replications and four treatments. The treatments constituted NPK 15:15:15 at the rate of $0,90,120$ and $150 \mathrm{~kg} / \mathrm{ha}$ designated as $\mathrm{T}_{1}, \mathrm{~T}_{2}, \mathrm{~T}_{3} \& \mathrm{~T}_{4}$ are presented in (Table 1).

Table 1. Experimental treatments.

\begin{tabular}{ll}
\hline Treatment & Fertilizer rate applied \\
\hline Treatment $\mathrm{T}_{1}$ & Control with no fertilizer application \\
Treatment $\mathrm{T}_{2}$ & $90 \mathrm{~kg} / \mathrm{ha}$ \\
Treatment $\mathrm{T}_{3}$ & $120 \mathrm{~kg} / \mathrm{ha}$ \\
Treatment $\mathrm{T}_{4}$ & $150 \mathrm{~kg} / \mathrm{ha}$ \\
\hline
\end{tabular}

Two hybrids of Okra were used as experimental materials obtained from Indo-American Hybrid Seed Company, India; Okra-WASA-HyOKR-1 and Okra-WASA-HyOKR-2. Seeds were treated with Thiram for dressing. Planting was done on $11^{\text {th }}$ January, 2017 with inter and intra row spacing of $60 \mathrm{~cm} \times 70 \mathrm{~cm}$ with two rows per bed. Seedlings were thinned down to one per hill at two weeks after sowing and standard agronomic practices were done when necessary. To ensure augmentation of unremitting soil moisture content and the availability of applied nutrients, plants were watered using watering-can virtually during the growing season. Recommended cultural practices were done as and when needed. Harvesting commenced on the $4^{\text {th }}$ April 2017 with three days harvesting interval throughout harvesting period. Data was recorded on plant height, stem girth, and leaf area (length $\mathrm{x}$ width centimeter) were measured using a ruler at 4, 8 and 10 Week After Plant and at harvest, number of leaves at harvest, pod length, pod diameter, number of pods plant $^{-1}$, fresh pod weight plant $^{-1}$ and 100 - seed weight. Data were subjected to analysis of variance using Gen Stat $12^{\text {th }}$ Edition (Numerical Algorithms Group) to separate significant treatment means.

\section{Results}

\section{Presentation of vegetative and yield components performance for Okra-WASA-HyOKR-1}

Vegetative as well as yield related performances for OkraWASA-HyOKR-1 are indicated in Figure 1. \& Table 2. Statistically, analysis showed highly significant $(\mathrm{P}<0.05)$ variations among treatments for plant height $(\mathrm{PH})$ at 10 Weeks After Planting, stem girth (SG) at 4 Week After Planting and leaf area (LA) 4, 8 \& 10 Week After Planting while PH and SG at 4 \& 8 Week After Planting had no significant variances with respect to vegetative parameters. Furthermore, result revealed that $\mathrm{T}_{2}(25.2 ; 35.1 \mathrm{~cm})$ and $\mathrm{T}_{4}(56.9 \mathrm{~cm})$ treatments recorded tallest plant heights followed by $\mathrm{T}_{2}(24.0,34.4 \& 50.1 \mathrm{~cm})$ while $\mathrm{T}_{1}(18.8,28.4 \& 33.3 \mathrm{~cm})$ had the shortest plant heights at 4,8 \& 10 Week After Planting respectively Table 2. Correspondingly, $\mathrm{T}_{4} \& \mathrm{~T}_{2}(38.9,65.5 \& 44.8 \mathrm{~cm})$ exhibited the largest $S G$ and $T_{1}(21.7,33.0 \& 52.0 \mathrm{~cm})$ the least values at 4,8 \& 10 Week After Planting. Additionally, the widest and narrowest LA at 4, 8 \& 10 Week After Planting was observed in $\mathrm{T}_{3}\left(131.3,135.8 \& 158.5 \mathrm{~cm}^{2}\right)$ and $\mathrm{T} 1(120.8,121.83 \& 128.1$ $\mathrm{cm}^{2}$ ) respectively as shown in (Figure 1$)$.

With respect to yield and yield components, length of pod (LP), fresh pod weight (FPW), width of pod (WP), number of pod plant $^{-1}$, and 100 seed weight $(\mathrm{SW})$ had significant differences $(\mathrm{P}<0.05)$. The longest $(22.8 \mathrm{~cm})$ and heaviest $(112.7 \mathrm{~g})$ fruit were recorded by $\mathrm{T}_{3}$ followed by $\mathrm{T}_{2}(19.1 \mathrm{~cm} \mathrm{\&}$ $101.3 \mathrm{~g})$ with $\mathrm{T}_{1}$ having the shortest $(11.7 \mathrm{~cm})$ and lightest $(52.3$ $\mathrm{g})$ concurrently. The width of pod in $\mathrm{T} 3(31.2 \mathrm{~cm})$ was greater than the rest of treatments and as usual, $T_{1}$ indicated the least value $(14.6 \mathrm{~cm})$ respectively. The average NP produced plant ${ }^{-1}$ was indicated by $\mathrm{T}_{2} \& \mathrm{~T}_{3}$ (4.0) with the least of fruit produced by $\mathrm{T}_{1}(2.0)$. Of the 100 seed weight, $\mathrm{T}_{3}(106.7 \mathrm{~g})$ followed by $\mathrm{T}_{2}$ $(103.3 \mathrm{~g})$ with $\mathrm{T}_{1}(60.3 \mathrm{~g})$ accounting for the lowest seed weight (Table 2).

\section{Presentation of vegetative and yield components performance for Okra-WASA-HyOKR-2}

Figure 2 \& Table 3 display vegetative, yield and yield components performances for Okra-WASA-HyOKR-2 respectively. Except for $\mathrm{PH}$ at $4 \mathrm{WAP}$, all other vegetative parameters (PH at $8 \& 10$ Week After Planting; SG at 4, 6 \& 10 Week After Planting and LA 4, 8 \& 10 Week After Planting were extremely significant $(\mathrm{P}<0.05)$ differences. Result showed that $\mathrm{T}_{4}(33.8 ; 43.2 \mathrm{~cm})$ and $\mathrm{T}_{3}(66.9 \mathrm{~cm})$ treatments exhibited tallest plant heights and $\mathrm{T}_{1}(22.7,31.2 \& 41.0 \mathrm{~cm})$ had the shortest plant heights at $4,8 \& 10$ Week After Planting congruently Figure 2. For SG at $4 \& 8$ WAP, $\mathrm{T}_{2}(35.2 ; 44.8$ $\mathrm{cm})$ recorded the largest which was closely followed by $\mathrm{T}_{3}$ $(34.5 ; 42.4 \mathrm{~cm})$ while $\mathrm{T}_{1}(22.7 ; 31.7 \mathrm{~cm})$ exhibited the least values. Conversely, at 10 Week After Planting, $\mathrm{T}_{4}(63.3 \mathrm{~cm})$ had the largest $\mathrm{SG}$ and $\mathrm{T}_{1}(39.9 \mathrm{~cm})$ the smallest as indicated in (Figure 2).

Furthermore, analysis indicated that $\mathrm{T}_{3}(141.8,149.7 \&$ $\left.160.3 \mathrm{~cm}^{2}\right)$ had the widest LA and the narrowest was observed in $\mathrm{T}_{1}\left(121.1,122.7 \& 125.6 \mathrm{~cm}^{2}\right)$ at $4,8 \& 10$ Week After Planting respectively. Yield components were highly significant $(\mathrm{P}<0.05)$ with respect to length of pod (LP), fresh pod weight (FPW), width of pod (WP), number of pod plant ${ }^{-1}$, and 100 seed weight $(\mathrm{SW})$ had. The longest $(30.9 \mathrm{~cm})$ and heaviest $(112.3 \mathrm{~g})$ fruit were recorded by $\mathrm{T}_{4} \& \mathrm{~T}_{2}$ and the least values were obtained 


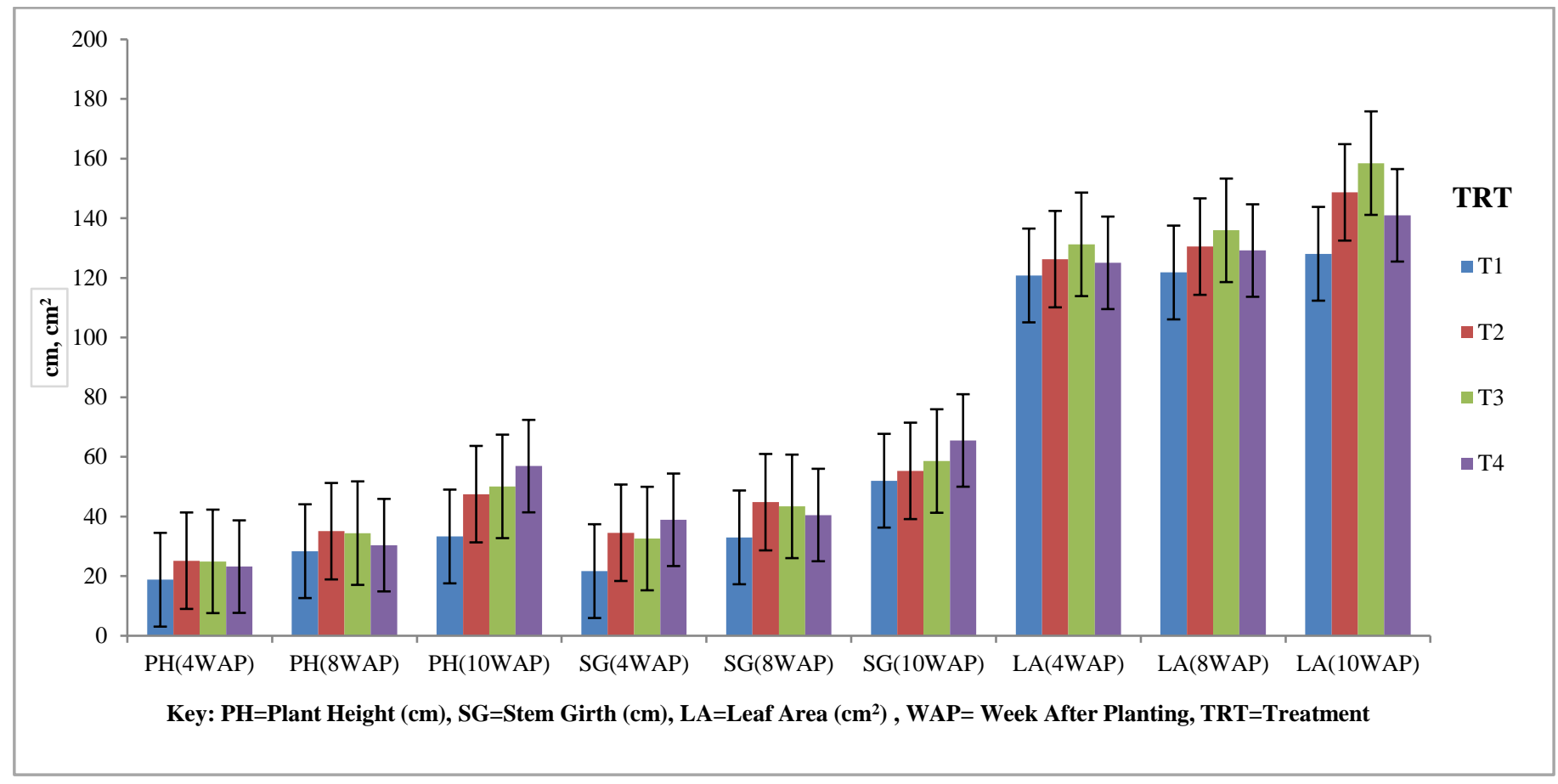

Figure 1. Mean values of vegetative parameters as affected by fertilizer application (okra-wasa-hyokr-1).

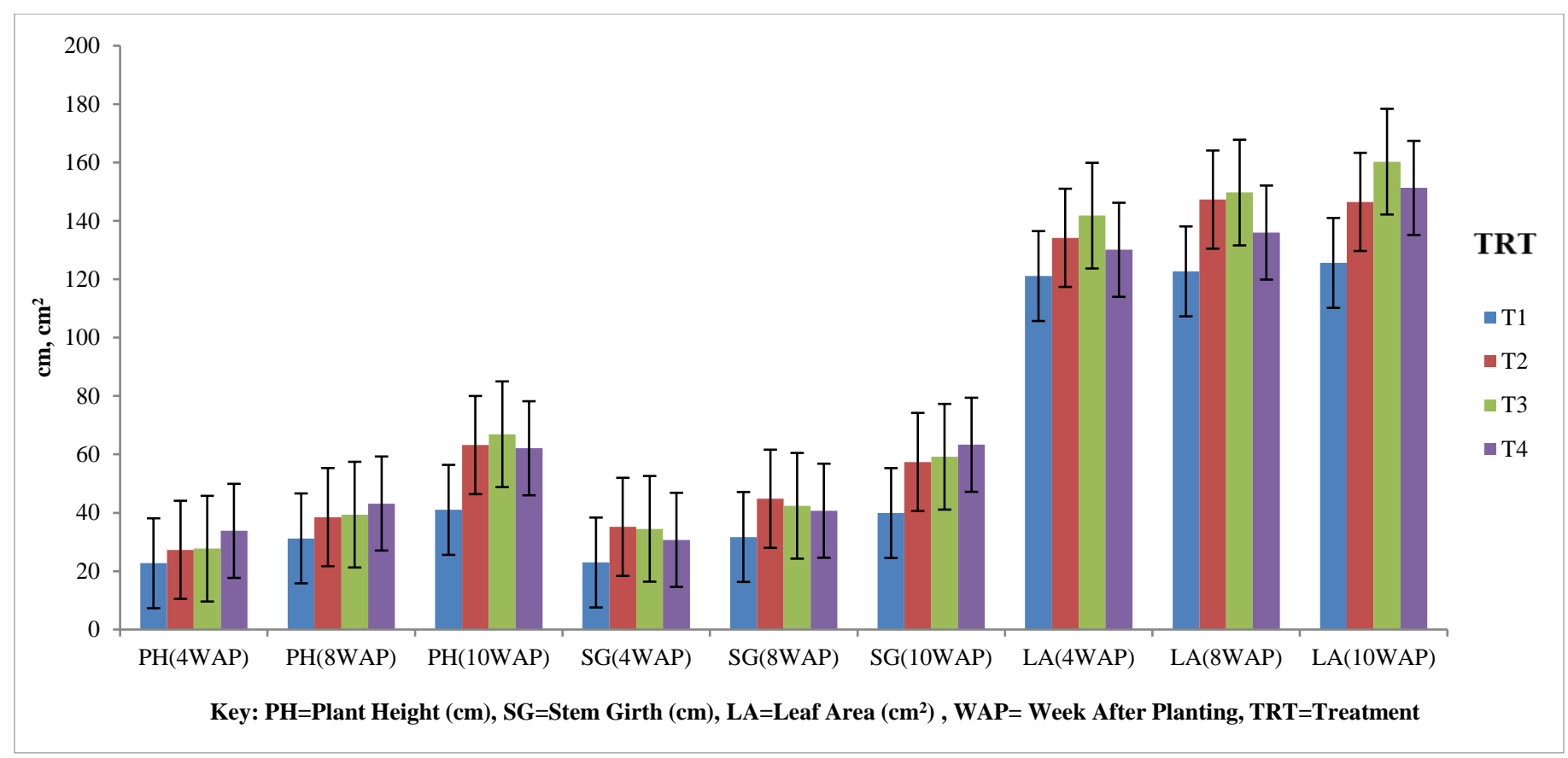

Figure 2. Mean values of vegetative parameters as affected by fertilizer application (okra-wasa-hyokr-2).

Table 2. Mean values of yield components parameters as affected by fertilizer application.

\begin{tabular}{|c|c|c|c|c|c|c|}
\hline Hybrid & Treatment & & & Parameters & & \\
\hline & & $\begin{array}{l}\text { Length of } \\
\text { pod plant } \\
(\mathrm{cm})\end{array}$ & $\begin{array}{l}\text { Fresh pod } \\
\text { weight } \\
\text { (g) }\end{array}$ & $\begin{array}{l}\text { Width of } \\
\text { pod plant }{ }^{-1} \\
(\mathrm{~cm})\end{array}$ & $\begin{array}{l}\text { Number of } \\
\text { pod plant }^{-1}\end{array}$ & $\begin{array}{l}100 \text { seed } \\
\text { weight } \\
\text { (g) }\end{array}$ \\
\hline \multirow[t]{4}{*}{ Okra-WASA-yOKR-1 } & $\mathrm{T}_{1}$ & 11.7 & 52.3 & 14.6 & 2.0 & 60.3 \\
\hline & $\mathrm{T}_{2}$ & 19.1 & 101.3 & 26.6 & 4.0 & 103.3 \\
\hline & $\mathrm{T}_{3}$ & 22.0 & 112.7 & 27.1 & 4.0 & 106.7 \\
\hline & $\mathrm{T}_{4}$ & 18.7 & 100.7 & 31.2 & 3.0 & 92.3 \\
\hline P. value & & 0.023 & 0.001 & 0.025 & 0.001 & 0.008 \\
\hline CV (\%) & & 17.1 & 8.4 & 19.4 & 9.1 & 12.4 \\
\hline
\end{tabular}


Table 3. Mean values of yield components parameters as affected by fertilizer application.

\begin{tabular}{|c|c|c|c|c|c|c|}
\hline \multirow[t]{2}{*}{ Hybrid } & \multirow[t]{2}{*}{ Treatment } & \multicolumn{5}{|c|}{ Parameters } \\
\hline & & $\begin{array}{l}\text { Length of } \\
\text { pod plant }{ }^{-1} \\
(\mathrm{~cm})\end{array}$ & $\begin{array}{l}\text { Fresh pod } \\
\text { weight } \\
\text { (g) }\end{array}$ & $\begin{array}{l}\text { Width of } \\
\text { pod }^{-1} \\
(\mathrm{~cm})\end{array}$ & $\begin{array}{l}\text { Number of } \\
\text { pod plant }^{-1}\end{array}$ & $\begin{array}{l}100 \text { seed } \\
\text { weight } \\
\text { (g) }\end{array}$ \\
\hline \multirow[t]{4}{*}{ Okra-WASA-yOKR-2 } & $\mathrm{T}_{1}$ & 11.1 & 49.0 & 15.1 & 3.0 & 55.0 \\
\hline & $\mathrm{T}_{2}$ & 26.4 & 112.3 & 35.4 & 4.0 & 102.0 \\
\hline & $\mathrm{T}_{3}$ & 28.7 & 110.7 & 37.2 & 3.0 & 107.0 \\
\hline & $\mathrm{T}_{4}$ & 30.9 & 110.7 & 29.7 & 4.0 & 117.0 \\
\hline P. value & & 0.001 & 0.003 & 0.001 & 0.034 & 0.001 \\
\hline CV $(\%)$ & & 10.9 & 13.9 & 12.8 & 13.2 & 5.9 \\
\hline
\end{tabular}

by $\mathrm{T}_{1}(11.1 \mathrm{~cm} \& 49.0 \mathrm{~g})$ respectively. The width of pod in $\mathrm{T}_{3}$ $(37.2 \mathrm{~cm})$ was greater than the rest of treatments with $\mathrm{T}_{1}$ exhibiting the least value $(15.1 \mathrm{~cm})$ successively. The highest NP produced plant ${ }^{-1}$ was recorded by $\mathrm{T}_{2} \& \mathrm{~T}_{4}$ (4.0) with $\mathrm{T}_{1} \& \mathrm{~T}_{3}$ accounting for the least values (3.0). Of the 100 seed weight, $\mathrm{T}_{4}$ $(117.0 \mathrm{~g})$ followed by $\mathrm{T}_{3}(107.0 \mathrm{~g})$ with $\mathrm{T}_{1}(55.0 \mathrm{~g})$ accounting for the lowest seed weight (Table 3).

\section{Discussion}

Variations observed among treatments with respect to vegetative and yield traits for the two evaluated Okra hybrids could be attributed to genetic differences of the tested material in addition to fertilizer applied and inherent soil fertility at time of experimentation. Result obtained for $\mathrm{PH}, \mathrm{SG}$, and LA is in conformity with some authors including Olowoake et al. (2015) and Simon (2013) who reported similar values and ascribed it to the increase application of NPK fertilizer. Moreover, according to Yadav et al. (2004), increase in PH could be associated with the application of NPK fertilizers. The N component might have enhanced cell disintegration and reintegration of more tissues resulting in luxuriant vegetative growth and thereby increased PH and other morphological characters (Simon, 2013). Conversely, result for plant height is inconsistent with Firoz (2009) and Sultana (2013) who reported lower values in their investigations. The variability observed in the stem girth among treatments and tested material might be imputed to effective and efficient uptake and utilization of available nutrients for growth and development of the crop. According Kanneh et al. (2016) plant growth can be influenced by application of fertilizer in addition to inherent soil fertility. Result of this study further corroborates with that of Olaiya et al. (2015) who recorded similar values when they assessed the impact of poultry manure on fruit yield and yield components of okra.

However, the result for SG disagrees with that of Simon (2013) who observed lower values in his investigation. Comparatively, wider leaf area observed on the rate of fertilizer is in accordance with Rosati et al. (2001) and Lemaire et al. (2005) who stated that in solanaceous plants, increasing $\mathrm{N}$ containing fertilizer rates could lead to a corresponding increase in leaf area, light-interception and dry matter partition. Nevertheless, application of NPK above $120 \mathrm{~kg} \mathrm{ha}^{-1}$ showed no incremental advantage with respect to leaf area. Besides the amount of nutrient applied could have influenced the physicochemical properties and nutrient content of the soil that might have impacted leaf area (Simon, 2013). According to Lawlor (2002) leaf growth is substantially affected by increasing $\mathrm{N}$ level and suggested that leaf area might be owing to adequate supply of $\mathrm{N}$ for high photosynthetic activity.

The result is in agreement with Amjad et al. (2002) who suggested that application of additional fertilizer beyond a specific dose might not be effective. The highly significant differences observed in fruit length, fresh pod weight and width of pod plant ${ }^{-1}$ could be attributed to genetic differences and ability to take up essential elements ( $\mathrm{P}, \mathrm{K}, \mathrm{Fe}, \mathrm{Zn}$ and $\mathrm{B}$ ) for translocation to economic yield of okra.

It is further described to the differences in the ability to produce and retain high number of flowers that developed into fruits. Of the two evaluated materials, the one which had the least number of fruits plant $^{-1}$ possibly had about $50 \%$ of its flowers dried up and fell off without further development. The treatment which produced the highest fruit suggests that it supply sufficient plant nutrients in contrast to treatment that produced the least. Moreover, Godia (2014) attributed fruit number variability observed in Tomato genotypes to possibility of better genetic components. Differences observed in fresh pod and 100 seed weights might be related to possibility of possession of higher stomata conductance, better partitioning of photosynthetic materials towards economic yield and better genetic structure. Result conforms to findings reported by Kanneh et al. (2016).

\section{Conclusion}

The study shows the two exotic okra assessed are adaptable to Sierra Leone climatic conditions and have huge yield potential if suitable conditions exist. However, there is need for further evaluation of material across agroecological zones of Sierra Leone especially predominantly vegetable growing areas.

\section{Acknowledgements}

Authors acknowledge Sierra Leone Agricultural Research Institute (SLARI) for logistical support. Mr. Solomon Bindi and James Papa, Field Technicians of the Kabala Horticultural Crops Research Centre (KHCRC) Site, Ogoo Farm for their energetic participation during the experimentation.

\section{References}

Adekiya, A. O., Agbede, T. M., Aboyeji, C. M., Dunsin, O., Ugbe, J. O. (2019): Green manures and NPK fertilizer effects on soil properties, growth, yield, mineral and vitamin $\mathrm{C}$ composition of okra (Abelmoschus esculentus (L.) Moench). 
Journal of the Saudi Society of Agricultural Sciences, 18 (2), pp. 218-223. doi: http://dx.doi.org/ 10.1016/j.jssas.2017.05.005

Amjad, M., Sultan, M., Anjum, M. A., Ayyub, C. M. (2002): Response of okra (Abelmoschus esculentus (L.) Moench) to various doses of $\mathrm{N} \& \mathrm{P}$ and different plant spacings. Pakistan Journal of Resource Science. 13(1): 19-29. ISSN 1021-1012

Firoz, Z. A. (2009): Impact of Nitrogen and Phosphorus on the Growth and Yield of Okra (Abelmoschus esculentus (L.) Moench) in hill slope condition. Bangladesh Journal Agricultural Resources. 34(4): 713-72

Godia, A. K. G (2014): Evaluation of some introduced fresh market tomato (Solanum lycopersicum L) for genetic variability and adaptability in Ghana using Morphological and molecular markers. School of Graduate Studies, Department of Crop and Soil Sciences, Kwame Nkrumah University of Science and Technology, Kumasi, Ghana.

Ijoyah, M. O., Dzer, D. M. (2012): Yield performance of Okra (Abelmoschus esculentus (L.) Moench) as affected by time of planting maize in Makurdi, Nigeria. International Scholarly Research Network; ISRN Agronomy. 485810, 7 pages. Doi: $10.5402 / 2012 / 485810$

Kanneh, S. M., Osei, M. K., Akromah, R., Gyau, J. (2016): Generation mean analysis of yield and yield components of early generations of interspecific crosses of tomato (Solanum lycopersicum L.). International Journal Plant Breeding and Genetics.10: 98-103. DOI:10.3923/ijpbg.2016.98.103

Konyeha, S., Alatise, M. O. (2013): Yield and water use of okra (Abelmoschus esculentus (L.) Moench) under water management strategies in Akure, South-Western city of Nigeria. International Journal Emerging Technology and Advance Engineering. 3(9):8-12. Website: www.ijetae.com

Lawlor, D. W. (2002): Carbon and nitrogen assimilation in relation to yield: Mechanisms are the key to understanding production systems. Journal of Experimental Botany 53: 773787.

Lemaire, G., Avice, J. C., Kim, T. H., Ourry, A. (2005): Developmental changes in shoot $\mathrm{N}$ dynamics of lucerne (Medicago sativa L.) in relation to leaf growth dynamics as a function of plant density and hierarchical position within the canopy. Journal of Experimental Botany 56: 935-943. DOI:10.1093/jxb/eri084

Madisa, M. E., Mathowa, T., Mpofu, C., Oganne, T. A. (2015): Effects of plant spacing on the growth, yield and yield components of Okra (Abelmoschus esculentus (L.) Moench) in
Botswana. American Journal of Experimental Agriculture. 6(1); 7-14. DOI:10.9734/AJEA/2015/14199

Ojo, G. O. S., Richard, B. I., Iorlamen, T. (2012): Evaluation of okra (Abelmoschus esculentus (L.) Moench) cultivars for dry season production in the Southern Guinea Savanna ecology of Nigeria. International Journal of Agronomy and Agricultural Research (IJAAR): Vol. 2, No. 5, p. 13-18. http://www.innspub.net

Olaiya, A. O., Atayese, M. O., Okeleye, K. A., Arowolo, T. O., Oluwole, S. O. (2015): Impact of poultry manure on fruit yield and yield components of inland valley okra (Abelmoschus esculentus (L.) Moench) in a forest-Savannah transition ecology of Nigeria. Net Journal of Agricultural Science Vol. 3(4), pp. 93 98. ISSN: 2315-9766

Olowoake, A. A, Ojo, J. A., Osunlola, O. S. (2015): Growth and yield of okra (Abelmoschus esculentus (L.) Moench) as influenced by NPK, jatropha cake and organomineral fertiliser on an Alfisol in Ilorin, Southern Guinea Savanna of Nigeria. Journal of Organic Systems. 10(1). SSN 1177-4258

PCARRD, (2007): Philippines Council for Agriculture, Forestry and natural Resource Research and Development. http;//www.pcarrd.dost. gov.ph/index.htm.

Politud, E. R. R. (2016): Effects of Artificial Defoliations on the Growth and Yield of Okra (Abelmoschus esculentus L) (Moench.) CV 'Smooth Cayene' Under Mid-Elevation Condition. International journal of Scientific and Technology Research. Vol. 5, Issue 04. ISSN 2277-8616. www.ijstr.org

Rosati, A., Badeck, F. W., Dejong, T. M. (2001): Estimating canopy light interception and absorption using leaf mass per unit leaf area in Solanum melongena. Annals of Botany 88: 101-109. https://doi.org/10.1006/anbo.2001.1433

Simon Osei-Assibey (2013): Impact of Different Levels of Nitrogen Fertilizer on The Population Dynamics and Within Plant Distribution of Podagrica Species and Yield of Okra. Degree of Bachelor in Agriculture, Department of Crop and Soil Sciences, Kwame Nkrumah University of Science and Technology, Kumasi, Ghana.

Sultana, S. (2013): Development of high yielding and tomato lines through diallel cross (MSc Thesis, pp. 44-45). Bangladesh Agricultural University, Mymensingh.

Yadav, P., Singh, P., Yadav, R. L., Lal, R. (2004): Ameliorative organic manures and nitrogen levels on okra. Haryana. Journal of Horticultural Science 33: 124-126. 